\title{
Particle-Associated Polycyclic Aromatic Hydrocarbons and their Dry Deposition Fluxes from a Bus-Station in the Rio de Janeiro Metropolitan Area, Brazil
}

\author{
Mauro C. S. Machado, ${ }^{a}$ Josiane Loyola, ${ }^{b}$ Simone L. Quiterio, ${ }^{b, c}$ Gisele O. da Rocha, ${ }^{d, e, f}$ \\ Jailson B. de Andrade ${ }^{d, e}$ and Graciela Arbilla ${ }^{*, b}$
}

${ }^{a}$ Analytical Solutions, Rio de Janeiro-RJ, Brazil

${ }^{b}$ Instituto de Química, Universidade Federal do Rio de Janeiro, 21949-900 Rio de Janeiro-RJ, Brazil

${ }^{c}$ Centro Federal de Educação Tecnológica de Química de Nilópolis, Unidade Maracanã, Rua Senador Furtado, 121, Maracanã, 20270-020 Rio de Janeiro-RJ, Brazil

'Instituto de Química, Universidade Federal da Bahia, Campus de Ondina, 40170-290 Salvador-BA, Brazil

${ }^{e}$ Centro Interdisciplinar de Energia e Ambiente, Universidade Federal da Bahia, 40110-040 Salvador-BA, Brazil

IInstituto Nacional de Ciência e Tecnologia de Energia e Ambiente, Universidade Federal da Bahia, 40170-290 Salvador-BA, Brazil

\begin{abstract}
Amostras de material particulado total e MP ${ }_{10}$ foram coletadas entre agosto de 2006 e fevereiro de 2007 na estação rodoviária Prefeito José Carlos Lacerda. Foram analisados os 16 HPAs considerados prioritários, emitidos pelos veículos pesados em condições típicas de operação, usando CG/EM. A $\Sigma$ HPA correspondeu a 0,0018\% da massa de MPT e 0,0012\% da massa de $\mathrm{MP}_{10} \mathrm{O}$ conteúdo total de HPAs foi de 3,57 $\mathrm{ng} \mathrm{m}^{-3}$ e 2,59 $\mathrm{ng} \mathrm{m}^{-3}$ para o MPT e o $\mathrm{MP}_{10}$, respectivamente. A contribuição dos compostos carcinogênicos, conforme a USEPA, (B [a]An, B [b]F, B[k]F, B[a] Py, IPy e DB[ah]A) foi $1,86 \mathrm{ng} \mathrm{m}^{-3}$ (52\% do total de HPAs) e $1,40 \mathrm{ng} \mathrm{m}^{-3}$ (54\% do total de HPAs), para as amostras de MPT e MP ${ }_{10}$, respectivamente. As relações características e a análise estatística multivariada deram, em geral, resultados similares aos obtidos para poeira de solos, exceto para a relação Flt/(Flt+Py), 0,34, compatível com emissões de diesel. Os fluxos de deposição seca estão no intervalo 0,022-0,603 e 0,016-0,436 $\mathrm{g} \mathrm{m} \mathrm{m}^{-2} \mathrm{dia}^{-1}$ para os compostos contidos no MPT e MP ${ }_{10}$, respectivamente.
\end{abstract}

Total particulate matter and $\mathrm{PM}_{10}$ samples were collected from August 2006 to February 2007 in Mayor José Carlos Lacerda bus station. 16 priority PAHs compounds emitted by heavy-duty vehicles on typical conditions of operation were analyzed by using GC/MS. $\Sigma \mathrm{PAH}$ accounted for $0.0018 \%$ of the TSP mass and $0.0012 \%$ of the $\mathrm{PM}_{10}$ mass. Total PAH contents on the particle phase were $3.57 \mathrm{ng} \mathrm{m}^{-3}$ and $2.59 \mathrm{ng} \mathrm{m}^{-3}$ for TSP and $\mathrm{PM}_{10}$, respectively. Contributions of carcinogenic USEPA priority PAHs (B[a]An, B[b]F, B[k]F, B[a]Py, IPy and DB[ah]A) were $1.86 \mathrm{ng} \mathrm{m}^{-3}(52 \%$ of total PAHs) and $1.40 \mathrm{ng} \mathrm{m}^{-3}$ (54\% of total PAHs), for TSP and $\mathrm{PM}_{10}$ samples, respectively. Diagnostic ratios and multivariate statistical analysis were, in general, similar to those reported for soil dust except for the Flt/Flt+Py) ratio, 0.34, compatible with diesel emissions. Dry deposition fluxes were in the range of 0.022-0.603 and 0.016-0.436 $\mu \mathrm{g} \mathrm{m}^{-2} \mathrm{day}^{-1}$ for compounds in TSP and $\mathrm{PM}_{10}$, respectively.

Keywords: polycyclic aromatic hydrocarbons, TSP, $\mathrm{PM}_{10}$, diagnostic ratios, bus station, dry deposition, diesel emissions

\section{Introduction}

The atmosphere is the major transport pathway for the movement of PAHs through the global environment. Once

\footnotetext{
*e-mail: graciela@iq.ufrj.br
}

they are released into the atmosphere, PAHs can redistribute between gas and particle phases according to their vapor pressures and atmospheric conditions, and are subjected to removal mechanisms such as oxidative and photocatalytic reactions and wet and dry deposition. ${ }^{1,2}$ The majority of PAHs (70-90\%) is sorbed on suspended particles at ambient 
temperature. Lighter PAHs with 2-3 benzene rings are mostly found in the gas phase while the heavier ones are mainly associated with airborne particles. The carcinogenic larger PAHs (5-7 rings) are associated with particles in the atmosphere. Some of the 3 and 4 rings PAHs are also bound to particles. Also, most of the mutagens in ambient air were proved to be particle-associated. Moreover, PAHs are mostly sorbed on small inhalable particles mainly on airborne particles of submicron diameter which can deposit in the respiratory tract, hence increasing the potential hazardous effects. ${ }^{3,4}$

PAHs are ubiquitous environmental contaminants. Both the United States Environmental Protection Agency (US EPA) and the European Environmental Agency have mentioned them as priority pollutants. They are originated from both natural and anthropogenic sources. Sources related to energy production are the most important in releasing PAHs. They can be classified as either pyrogenic (mainly from incomplete combustion of organic materials, such as coal, oil, vegetation or fossil fuels) or petrogenic inputs. ${ }^{5-7}$ PAHs have received attention in air pollution studies because some of these compounds, for instance, benzo[a]pyrene, chrysene, indeno[1,2,3-cd]pyrene, and benzo[b]fluoranthene, have produced carcinogenic, genotoxic and/or mutagenic effects in animals. Accordingly, breathing PAHs may represent a health hazard for humans. ${ }^{8-10}$

The risk associated with human exposure to atmospheric PAHs is higher in urban environments ${ }^{8}$ where high vehicle density and the dispersion of atmospheric pollutants contribute to the increase of their concentrations. Indeed, in urban areas, exhaust from diesel and gasoline vehicles play an important role on PAH emissions. Otherwise, emissions of PAHs on highways are strongly influenced by heavyduty diesel vehicles. ${ }^{11}$ Occurrence of PAHs in ambient air is a growing concern due to the continuous nature of exposures and the size of populations at risk, especially in urban, suburban and industrial areas. Therefore, in light of the mutagenicity, carcinogenicity and ubiquity of some PAHs in the atmosphere, the setting of air quality standards and guidelines to limit human exposure should be of primary concern for public health policy. However, difficulties in interpreting heterogeneous experimental data and epidemiological findings ${ }^{9}$ limit the empirical data needed to establish standards or guidelines.

Several articles were published on the emissions of PAHs from mobile sources. ${ }^{12-19}$ Rogge et al.,$^{20}$ determined the chemical composition of organic fine particulate matter $\left(\mathrm{PM}_{2.5}\right)$ emitted from six non-catalyst vehicles, seven catalyst-equipped automobiles and two heavy duty diesel trucks. More than 100 organic compounds, including
PAHs, were determined in this work. In 1999, Marr et $a l .{ }^{21}$ determined the PAHs concentrations in gasoline and diesel fuel samples collected in northern California and also in particulate matter collected in a tunnel using both filter $\left(\mathrm{PM}_{2.5}\right)$ and impactor methods. Emission factors were determined separately for light-duty vehicles and for heavyduty diesel trucks. The authors reported that light-duty vehicles were found to be a significant source of heavier (four- and five-ring) PAHs, whereas heavy-duty diesel engines were the dominant source of three-ring PAHs, such as fluoranthene and pyrene. The obtained results showed no correlation between heavy-duty diesel truck PAH emission factors and PAH concentrations in diesel fuel. In a rather recent study conducted in the centre of Athens (Greece), ${ }^{22}$ the concentration of PAHs and metals adsorbed to total suspended particulate and finer fractions of airborne particulate matter $\left(\mathrm{PM}_{10}\right.$ and $\left.\mathrm{PM}_{2.5}\right)$ were determined. The authors reported that the most common PAHs in $\mathrm{PM}_{10.2}$ and $\mathrm{PM}_{2.1}$ were pyrene, phenanthrene, acenapthylene and fluoranthene, which are associated with diesel and gasoline exhaust particles. In another study, Turrio-Baldassarri et al. ${ }^{23}$ compared the emissions of diesel, a blend of diesel and $20 \%$ vegetable oil and compressed natural gas engines. The experimental design focused carcinogenic compounds on particulate matter and vapor phase. The results were compared with a previous work ${ }^{24} \mathrm{on}$ the emissions of diesel and biodiesel bus engines. Chrysene followed by benzo[a]anthracene, benzo[b]fluoranthene and benzo[k]fluoranthene were identified as the most abundant compounds.

Most of the data obtained in Brazilian cities refer to total suspended particles. ${ }^{625-43}$ Data for inhalable particles and $\mathrm{PM}_{2.5}$ are rather sparse. ${ }^{40,42,44-47}$ Some studies were fulfilled in locations highly affected by diesel emissions. Pereira et al..$^{38}$ determined 16 selected polycyclic aromatic hydrocarbons in total particulate matter, in the Lapa bus station (Salvador, Bahia). Pyrene, fluoranthene and chrysene showed the highest average concentrations. In January 2002, Tavares et $a l .{ }^{48}$ determined the concentrations of vapor phase polycyclic aromatic hydrocarbons at the Londrina Central Bus Station, where only dieselpowered vehicles circulated. The species that presented higher concentration were phenanthrene, fluorene and naphthalene. In 2006, Correa and Arbilla ${ }^{49}$ reported the analysis of the polycyclic aromatic compounds collected in the vapor and aerosol exhaust of a diesel engine. The major compounds were phenanthrene, fluorene and naphthalene. Clearly, PAHs with lower liquid vapor pressures are mainly found in the vapor phase ${ }^{38,50}$ while compounds with vapor pressures lower than $1 \times 10^{-3} \mathrm{~Pa}$ are mainly in the aerosol phase. 
The objective of this paper is to determine the 16 priority particle-associated (TSP and $\mathrm{PM}_{10}$ ) PAHs emitted by heavy-duty vehicles, fueled by diesel, on typical conditions of operation. The samplings were performed in a bus station located in the city of Duque de Caxias, in the State of Rio de Janeiro. The studied bus station is poorly ventilated and the intense and frequent movement and parking of buses (which remain with their motors on during passenger accesses) may cause releases of many kinds of hazardous chemicals to the atmosphere. As described bellow, emissions in that location are mainly due to diesel engines. The results are accordingly discussed.

\section{Experimental}

\section{Sampling site}

The sampling site was the Prefeito José Carlos Lacerda Bus Station, placed in the Centenário Quarter, in the city of

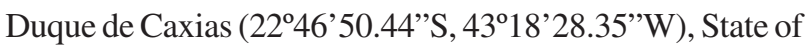
Rio de Janeiro. The city occupies an area of $468.3 \mathrm{~km}^{2}$ and has a population of about 842,890 inhabitants distributed in forty Quarters and four Districts. ${ }^{51}$ According to DETRAN, the total number of vehicles in the city is around 160,000 units. Nowadays, $64.7 \%$ of vehicles are fueled with gasohol (gasoline with $24 \%$ of ethanol), $11.7 \%$ with neat ethanol, $12.3 \%$ with compressed natural gas (CNG), $2.5 \%$ are flexfueled cars (gasohol and ethanol) and $8.8 \%$ are heavy-duty diesel vehicles. ${ }^{52}$ The city has about 3,000 buses and 690 micro-buses.

The bus station is located in a residential area with reduced commercial activity and no industries in its surroundings. There is no other activity inside the station except for traffic of buses. The station occupies a $10,621 \mathrm{~m}^{2}$ area in one floor and is composed by 8 platforms (each one for four vehicles) for arrivals and departures of urban heavy-duty diesel buses. The confluence of 14 bus lines coming from six other districts of Duque de Caxias and eight other cities of the Metropolitan Region of Rio de Janeiro occurs at the station. Besides the movement of arrival and departure, many vehicles that are waiting for the next departure remain with their motors on. Buses stay about one minute commuting in the station.

No other activities are developed in the bus station and its surroundings. Vehicle count was performed in parallel with particulate matter sampling. The total number of buses is about 180 vehicles a day and light-duty cars represent about $2 \%$ of the total flux. No noticeable differences in the vehicle flux were observed during weekdays. Since the only significant emission sources are buses, the location is representative of a diesel impacted environment.

\section{Sampling procedure}

The TSP and $\mathrm{PM}_{10}$ samplers were installed beside one of the platforms at a height of $2 \mathrm{~m}$ from ground level. TSP and $\mathrm{PM}_{10}$ samplings were performed twice a week using high volume samplers (Sibata, Japan) and borosilicate glass microfiber filters $(110 \mathrm{~mm}$ diameter, $0.22 \mathrm{~mm}$ thickness, Sibata, Japan). Samplings were performed randomly from Monday to Friday. No samplings were performed in the afternoon and at night because the main goal of this work was to identify typical emissions of diesel-powered vehicles. Experiments at night and during weekends were not possible to be performed because of security reasons and availability of samplers. Vehicles were counted in parallel with particulate matter sampling. A flow rate of $500 \mathrm{~L} \mathrm{~min}^{-1}$ and 6 hour sampling time were adopted for the collection of 66 samples (33 for TSP samples and 33 for $\mathrm{PM}_{10}$ samples) from August 2006 to February 2007 in Prefeito José Carlos Lacerda bus station. After sampling, the filters were wrapped with aluminum foil, placed inside sealed plastic bags and stored at $-20{ }^{\circ} \mathrm{C}$ up to 14 days until weighing, extraction and analysis. Due to instrumental availability, only TSP and $\mathrm{PM}_{10}$ samples were collected.

\section{Extraction procedure and analysis}

Gravimetric determinations were carried out as described in Method IO-3.1, 1999.53

Sixteen PAHs specified on USEPA Method $610^{54}$ in a mixture, internal standards (naphthalene-D8, acenaphthene-D10, phenanthrene-D10, chrysene-D12, and perylene-D12) and surrogates (2-Fluorobiphenyl and D14-Terphenyl) were obtained from AccuStandard (AccuStandard, USA).

Extraction procedures followed Method $3550 b^{55}$ as described by Quiterio et al. ${ }^{42}$ Briefly, surrogate mix was added to the filter samples before extraction procedure, then those filters were sonicated four times with $50 \mathrm{~mL}$ dichloromethane (DCM) for $15 \mathrm{~min}$ and then with $100 \mathrm{~mL}$ for $20 \mathrm{~min} .{ }^{56}$ The organic extract was filtered and concentrated to $2 \mathrm{~mL}$ on a rotatory evaporator. Surrogate recoveries ranged from 48 to $72 \%$. Afterwards, PAH concentrations were corrected according to the efficiency of recovery during extraction.

Prior to injection, $1 \mu \mathrm{g}$ of internal standards mix was added to the extracts. All samples were analyzed using a Gas Chromatograph (GC Agilent Model 6890, USA) hyphenised to a Mass Spectrometry selective detector (Agilent Model 5973, USA), equipped with a HP-5 $(30 \mathrm{~m} \times 0.25 \mathrm{~mm}$ dia. $\times 0.25 \mu \mathrm{m}$ film thickness, Agilent, 
USA) GC column. $1 \mu \mathrm{L}$ samples were injected on splitless mode at an injector temperature of $300{ }^{\circ} \mathrm{C}$. The carrier gas was helium at a constant flow of $1.2 \mathrm{~mL} \mathrm{~min}^{-1}$. Oven temperature was programmed as follows: $50^{\circ} \mathrm{C}(2 \mathrm{~min}) \rightarrow$ $300{ }^{\circ} \mathrm{C}\left(12{ }^{\circ} \mathrm{C} \mathrm{min}{ }^{-1}\right) \rightarrow 300{ }^{\circ} \mathrm{C}(10 \mathrm{~min})$. Quantitative analyses were performed using a single ion monitoring (SIM) method under $70 \mathrm{eV}$ of electron energy. Chromatographic peaks were identified and quantified, based on their GC-MS acquired retention times and mass spectra of the authentic standards used as reference: naphthalene (Na)-128, acenaphthylene (Acy)-152, acenaphthene (Ace)-153, fluorene (Flu)-166, phenanthrene (Phe)-178, anthracene (An)-178, fluoranthene (Flt)-202, pyrene (Py)-202, benzo[a]anthracene (B[a]An)-228, chrysene (Chry)-228, benzo[b]fluoranthene (B[b]F)-252, benzo[k]fluoranthene (B $[\mathrm{k}] \mathrm{F})-252$, benzo[a]pyrene $(\mathrm{B}[\mathrm{a}]$ Py)-252, indene[1,2,3-c,d]pyrene (IPy)-276, dibenz[a,h] anthracene (DB[ah]A)-278, and benzo[ghi]perylene (B [ghi]P)-276. Field blanks, which accompanied samples from the collecting sites, were used in order to avoid background contamination of results.

Quantification limit (QL) and detection limit (DL) were determined as $10 \mathrm{ng}$ and $8 \mathrm{ng}$, respectively. The QL was the first point (the point of lowest concentration) from each linear calibration curve. DL was determined from the standard deviation from the responses of seven replicates of the lowest point in the calibration curve, multiplied by the correspondent $\mathrm{t}$-factor for $95 \%$ confidence interval. Considering the total sampled air volume $\left(1600 \mathrm{~m}^{3}\right)$, the QL and DL from this method were estimated to be $0.006 \mathrm{ng} \mathrm{m}^{-3}$ and $0.005 \mathrm{ng} \mathrm{m}^{-3}$, respectively.

\section{Statistical analysis}

Experimental data were analysed using STATISTICA 6.0 (Statsoft, USA) software pack. Principal Component Analysis (PCA) and Cluster Analysis (CA), using Euclidian distances and Ward's Method, were also performed, as classification and ordination methods.

\section{Results and Discussion}

\section{PAH levels in TSP and PM 10 samples}

TSP levels were in the range of 39 to $52.4 \mu \mathrm{g} \mathrm{m}^{-3}$ and the arithmetic mean was $200 \mu \mathrm{g} \mathrm{m}^{-3}$. Similarly, values for $\mathrm{PM}_{10}$ ranged from 38 to $434 \mu \mathrm{g} \mathrm{m}^{-3}$, with a mean value of $210 \mu \mathrm{g} \mathrm{m}^{-3}$.

The concentrations of the studied PAH samples are shown in Table 1 . The average values (in $\mathrm{ng} \mathrm{m}^{-3}$ ) are mean values for the 33 samples (33 TSP and $33 \mathrm{PM}_{10}$ samples). Individual concentrations were between the detection limit for acenaphtylene, acenaphthene, anthracene and fluorene and 2.27 and $1.74 \mathrm{ng} \mathrm{m}^{-3}$ for benzo[ghi] perylene (B[ghi]P) for TSP and $\mathrm{PM}_{10}$, respectively. The concentrations of naphthalene (Na), acenaphtylene (Acy), acenaphthene (Ace), fluorene (Flu) are not reported because samplings were performed for rather long periods $(6 \mathrm{~h})$ in unfavorable temperature conditions. The platform area is not well ventilated and samples were collected in spring and summer when ambient temperatures are very high in Brazil. The obtained concentrations values are probably underestimated due to volatilization of the low molecular weight compounds. Long sampling periods may alter the chemical composition of samples because of volatilization, chemical and photochemical transformations leading to underestimated PAH concentrations. A comparative study of PAH concentrations determined in $\mathrm{PM}_{10}$ and GF/PUF (glass fiber filters and a polyurethane foam filter) samples collected at two urban stations in the city of Brno, Czech Republic, ${ }^{57}$ showed that the GF/PUF method gave an amount of low molecular weight U.S.EPA priority PAHs (Na, Acy, Ace, Flu, Phe, An, Flt, Py) several times higher than the high volume sampling of the $\mathrm{PM}_{10}$ fraction. Ciganek et al. ${ }^{57}$ concluded that sampling using the $\mathrm{PM}_{10}$ method could lead to an underestimation of overall PAH concentrations and, particularly, of low molecular weight compounds.

$\Sigma$ PAH accounted for $0.0018 \%$ of the TSP mass and $0.0012 \%$ of the $\mathrm{PM}_{10}$ mass. The total PAHs contents on

Table 1. PAH concentration ( $\mathrm{ng} \mathrm{m}^{-3}$ ) and PAH particle content of PM collected in this study (units in $\mu \mathrm{g} \mathrm{g}^{-1}$ )

\begin{tabular}{lcccccccccccc}
\hline & Phe & Flt & Py & B[a]An & Chry & B[b]F & B[k]F & B[a]Py & Ipy & DB[ah]A B[ghi]P & Total \\
\hline PAH concentration / $\left(\mathrm{ng} \mathrm{m}^{-3}\right)$ & & & & & & & & & & & & \\
TSP & 0.116 & 0.174 & 0.288 & 0.166 & 0.262 & 0.557 & 0.131 & 0.363 & 0.524 & 0.117 & 0.866 & 3.564 \\
PM $_{10}$ & 0.087 & 0.119 & 0.203 & 0.132 & 0.191 & 0.424 & 0.107 & 0.268 & 0.365 & 0.118 & 0.611 & 2.625 \\
PAH content / $\left(\mu \mathrm{g} \mathrm{g}^{-1}\right)$ & & & & & & & & & & & & \\
TSP & 0.58 & 0.87 & 1.44 & 0.83 & 1.31 & 2.78 & 0.65 & 1.81 & 2.61 & 0.58 & 4.32 & 17.78 \\
PM $_{10}$ & 0.41 & 0.57 & 0.97 & 0.63 & 0.91 & 2.02 & 0.51 & 1.28 & 1.74 & 0.56 & 2.91 & 12.49 \\
\hline
\end{tabular}


the particle phase were $17.8 \mu \mathrm{g} \mathrm{g}^{-1}$ and $12.5 \mu \mathrm{g} \mathrm{g}^{-1}$ for TSP and $\mathrm{PM}_{10}$, respectively. Individual PAH content on both particle phase fractions are described on Table 1. Contribution of carcinogenic USEPA priority PAHs (B[a]An, B[b]F, B[k]F, B[a]Py, IPy and DB[ah]A) were $9.27 \mu \mathrm{g} \mathrm{g}^{-1}$ (52\% of total PAHs) and $6.73 \mu \mathrm{g} \mathrm{g}^{-1}$ (54\% of total PAHs), respectively. Carcinogenic PAHs contributions show similar percentual values thus evidencing serious health concerns.

Unfortunately, there are few studies reporting PAH concentrations in Brazilian areas emitted from heavyduty diesel vehicles. ${ }^{38,48}$ Tavares Jr. et al..$^{48}$ determined the concentration of vapor phase PAHs at the central bus station of Londrina (Brazil) where only diesel-powered vehicles circulate. PAHs were collected using XAD-2 resin cartridges and analyzed by gas chromatography with both flame ionization and mass spectrometer detectors. Ten PAH were found (naphthalene, acenaphthylene, acenaphthene, fluorene, phenanthrene, anthracene, fluoranthene, pyrene, benzo(a)anthracene and chrysene) and the most abundant compounds were phenantrene, fluorene and naphthalene. Pereira et al. ${ }^{38}$ used a TSP high volume sampler with quartz fiber filters. Samples were collected at the Lapa bus station located in a downtown area of Salvador, Bahia (Brazil). Chrysene presented the highest average concentration but relative high concentrations were obtained for fluorantene, pyrene, benzo[a]anthracene, benzo[b]fluoranthene, benzo[k] fluoranthene, benzo[a]pyrene, indene[1,2,3-cd]pyrene and benzo[ghi]perylene as well. Our results are in quite good agreement with these data.

\section{Diagnostic ratios}

PAH concentrations and molecular ratios have been used to distinguish emissions and indicate the impact of different sources of airborne compounds. ${ }^{58-62}$

Diagnostic ratios between PAHs are presented in Table $2^{12,20,38,63-68}$ both for TSP and PM $_{10}$ samples. Ratios are very similar for $\mathrm{PM}_{10}$ and TSP samples. Values obtained in $\mathrm{PM}_{10}$ samples are indicated in italics.

In 2004, Manoli et al. ${ }^{12}$ published the PAHs profiles for several urban, industrial and geological sources, in particular diesel fueled buses, paved road dust and soil dust absorbed on $\mathrm{PM}_{10}$ samples. In general, diagnostic ratios for ambient urban samples were similar to those obtained for paved road and soil dust. Ratios obtained from the exhaust of diesel vehicles are rather different suggesting that the $\mathrm{PM}_{10}$ fraction has an important contribution of mechanical sources and ressuspension of dust. In Table 2, typical ratios for diesel vehicles, light cars, urban TSP and $\mathrm{PM}_{10}$ samples, paved road dust, soil dust are listed for comparison. Urban samples were those determined by Mantis et al. ${ }^{63}$ in an Aristotelous street, in downtown Athens, with dense vehicular traffic and commercial activities, and by Manoli et al. ${ }^{12}$ in the city center of Thessalonike, Greece, an area with high commercial activities and traffic density. It must be noted that the reported ratios are, in many cases, spread in a wide range of values and there is not a clear difference between diesel and gasoline emissions.

The sum of concentrations of the nine combustion PAHs (CPAH) (see Table 2) divided by the total concentration of PAHs gave the values 0.93 and 0.91 for TSP and $\mathrm{PM}_{10}$

Table 2. Diagnostic PAH ratios of samples obtained at Mayor José Carlos Lacerda Bus Station

\begin{tabular}{|c|c|c|c|c|c|c|c|}
\hline & $\begin{array}{c}\text { This study } \\
\text { TSP }\end{array}$ & $\begin{array}{c}\text { This study } \\
\text { PM }_{10}\end{array}$ & Diesel vehicles & Gasoline vehicles & Urban Samples & Soil dust & Paved road dust \\
\hline $\mathrm{CPAH} / \Sigma \mathrm{PAH}$ & $0.93 \pm 0.03$ & $0.91 \pm 0.17$ & $0.77 ;^{12} 0.88^{63}$ & $0.73 ; ;^{12} 0.60^{68}$ & $\begin{array}{c}0.95 ;^{12} 1.18 ;^{33} \\
0.92^{63}\end{array}$ & $0.89 ; ;^{12} 0.83^{12}$ & $\begin{array}{c}0.82 ;^{12} 0.86 ; ;^{12} \\
0.87^{12}\end{array}$ \\
\hline $\mathrm{B}[\mathrm{ghi}] \mathrm{Pe} / \mathrm{B}[\mathrm{a}] \mathrm{Py}$ & $2.44 \pm 0.80$ & $2.27 \pm 0.88$ & $\begin{array}{c}0.11 ;^{12} 3.69 ;^{65} \\
1.2-2.2^{64}\end{array}$ & $\begin{array}{c}3.05 ;^{12} 1.72 ;^{12} \\
2.5-3.3^{64}\end{array}$ & $\begin{array}{c}2.00 ;^{12} 1.26 ;^{33} \\
4.36^{63}\end{array}$ & $\begin{array}{c}1.18 ;^{.2} 0.25 ;^{12} \\
0.86^{12}\end{array}$ & $\begin{array}{l}2.70 ;^{12} 1.09 ;^{12} \\
3.67 ; ;^{12} 0.91^{20}\end{array}$ \\
\hline $\mathrm{IPy} /(\mathrm{Ipy}+\mathrm{B}[\mathrm{ghi}] \mathrm{Pe})$ & $0.37 \pm 0.05$ & $0.37 \pm 0.05$ & $\begin{array}{c}0.96 ;^{12} 0.35- \\
0.70^{64}\end{array}$ & $0.26 ;^{12} 0.51^{12}$ & $\begin{array}{c}0.38 ;^{12} 0.38 ;^{33} \\
0.32^{63}\end{array}$ & $0.61 ;^{12} 0.91^{12}$ & $\begin{array}{c}0.51 ;{ }^{12} 0.57 ; ;^{12} \\
0.52^{12}\end{array}$ \\
\hline $\mathrm{B}[\mathrm{a}] \mathrm{An} /(\mathrm{B}[\mathrm{a}] \mathrm{An}+$ Chry $)$ & $0.39 \pm 0.03$ & $0.40 \pm 0.08$ & $0.73 ;^{12} 0.37^{63}$ & $0.76 ;^{12} 0.58^{12}$ & $\begin{array}{c}0.43 ;^{: 12} 0.20 ;^{33} \\
0.40^{63}\end{array}$ & $0.29 ;^{12} 0.20^{12}$ & $\begin{array}{c}0.67 ; ;^{12} 0.42 ; ;^{12} \\
0.32 ;{ }^{12} 0.50^{65,66}\end{array}$ \\
\hline $\mathrm{Flt} /(\mathrm{Flt}+\mathrm{Py})$ & $0.37 \pm 0.03$ & $0.36 \pm 0.07$ & $\begin{array}{c}0.38 ;^{12} 0.46 ;^{63} \\
0.36^{20}\end{array}$ & $\begin{array}{c}0.14 ;^{12} 0.17 ;^{12} 0.47 ; ;^{67} \\
0.41 ; ;^{65,66} 0.40^{64}\end{array}$ & $\begin{array}{c}0.37 ;^{12} 0.34 ;^{33} \\
0.39^{63}\end{array}$ & $0.52 ;{ }^{12} 0.61^{12}$ & $\begin{array}{c}0.42 ;^{12} 0.52 ;^{12} \\
0.42^{64}\end{array}$ \\
\hline $\mathrm{B}[\mathrm{a}] \mathrm{Py} /(\mathrm{B}[\mathrm{a}] \mathrm{Py}+\mathrm{Chry})$ & $0.56 \pm 0.12$ & $0.55 \pm 0.15$ & $\begin{array}{c}0.38-0.65 ;{ }^{65,66} \\
0.46^{68}\end{array}$ & na & $0.18^{33}$ & na & na \\
\hline
\end{tabular}

CPAH: Flt +Py+B[a]An+Chry+B[b]F+B[k]F+B[a]Py+B[ghi]Pe+IPy.

${ }^{12}$ Manoli et al.; ${ }^{33}$ Pereira Netto et al.; ${ }^{63}$ Mantis et al.; ${ }^{20}$ Rogge et al.; ${ }^{64}$ Rogge et al.; $;{ }^{65}$ Kavouras et al.; ${ }^{66}$ Kavouras et al.; ${ }^{67}$ Sienra et al.; ${ }^{68}$ Oda et al.; na: not available. 
samples, respectively. This value is in the same range of previous reported ratios for downtown areas. ${ }^{12,63}$ As shown in Table 2, these values are also similar to those obtained for soil and road dust samples.

The ratios $\mathrm{B}$ [ghi]Pe/B[a]Py, calculated as 2.44 and 2.27 for TSP and $\mathrm{PM}_{10}$, respectively, are compatible with values reported for road dust and some urban areas. ${ }^{63}$ Values obtained directly from buses exhausts are significantly smaller, ranging from $0.11^{12}$ to $1.2-2.2 .^{63}$

Considering the carcinogenic compounds, the ratios, $\mathrm{B}[\mathrm{a}] \mathrm{An} /(\mathrm{B}[\mathrm{a}] \mathrm{An}+\mathrm{Chry})$ and $\mathrm{B}[\mathrm{a}] \mathrm{Py} /(\mathrm{B}[\mathrm{a}] \mathrm{Py}+\mathrm{Chry})$ were calculated as $0.38-0.39$ and $0.56-0.55$, respectively, values also associated to urban areas with high density traffic and road dust. ${ }^{12,63,65,66}$ The value determined from the direct exhaust of diesel buses is $0.73 .{ }^{12}$

The ratio Flt/(Flt+Py) was calculated as 0.37 and 0.36 for TSP an $\mathrm{PM}_{10}$, respectively. These values are in good agreement with the ratio obtained for diesel buses, ${ }^{12}$ diesel trucks ${ }^{20}$ and urban areas ${ }^{12,63}$ and they are also similar to the value obtained by Quiterio et $a l .{ }^{42}$ in an area with a high contribution of diesel buses and trucks. These data may be compared with those determined by Pereira et al. ${ }^{38}$ at the Lapa bus station in Salvador for TSP samples. The diagnostic ratios displayed in Table 2 were calculated using the mean concentrations reported by the authors. The value for the $\mathrm{CPAH} / \Sigma \mathrm{PAH}$ ratio is similar to that reported in this work. The other ratios are, in general, similar to those reported for soil dust ${ }^{12}$ except for the Flt/(Flt+Py) ratio, 0.34 , compatible with diesel emissions.

The benzo[a]pyrene equivalent carcinogenic power $(\mathrm{BaPE})^{69,70}$ was also estimated. This index tries to parameterize the health risk for humans related to ambient PAH exposition and is calculated by multiplying the concentrations of each carcinogenic congener, as follows:

$\mathrm{B}[\mathrm{a}] \mathrm{An} \times 0.06+\{\mathrm{B}[\mathrm{b}] \mathrm{F}+\mathrm{B}[\mathrm{k}] \mathrm{F}\} \times 0.07+\mathrm{B}[\mathrm{a}] \mathrm{Py}+$ $\mathrm{DB}[\mathrm{ah}] \mathrm{An} \times 0.6+\mathrm{IPy} \times 0.08$.

The calculated values are 0.17 and $0.41 \mathrm{ng} \mathrm{m}^{-3}$ for TSP and $\mathrm{PM}_{10}$ samples, respectively. These values do not represent a significant cancer risk for passengers and workers in the bus station area.

This is, to our knowledge, the first reported diagnostic ratio for a diesel fleet in Brazil and may be considered as a typical value for emissions of high-duty vehicles in the country. Anyway it is clear that a further study in the $\mathrm{PM}_{2.5}$ fraction is highly desirable in order to assess both the inhalable fraction and the fraction due predominately to combustion processes.

\section{Statistical analysis}

In order to obtain an insight on the main correlations among PAHs, cluster analysis (CA) and factorial analysis (FA) were applied for each set of data.

Table 3. Results of PCA for the correlation matrix $[33 \times 11]$ obtained with TSP and $\mathrm{PM}_{10}$ data at the bus station

\begin{tabular}{lcccc}
\hline & \multicolumn{2}{c}{ TSP } & \multicolumn{2}{c}{$\mathrm{PM}_{10}$} \\
& \multicolumn{2}{c}{$[33 \times 11]$} & & 2 \\
\hline PC & 1 & 2 & 1 & 2 \\
\hline Eigenvalues & 7.4 & 1.6 & 7.5 & 1.5 \\
\% total variance & 66.8 & 14.1 & 68.0 & 13.8 \\
\hline Loading & & & & \\
\hline Phe & $\mathbf{0 . 7}$ & 0.4 & $\mathbf{0 . 7}$ & 0.4 \\
Flt & $\mathbf{0 . 9}$ & 0.2 & $\mathbf{0 . 8}$ & 0.3 \\
Py & $\mathbf{0 . 9}$ & 0.2 & $\mathbf{0 . 8}$ & 0.3 \\
B[a]An & 0.2 & $\mathbf{0 . 9}$ & 0.2 & $\mathbf{0 . 9}$ \\
Chry & 0.2 & $\mathbf{1 . 0}$ & 0.2 & $\mathbf{0 . 9}$ \\
B[b]F & $\mathbf{0 . 8}$ & 0.2 & $\mathbf{0 . 9}$ & 0.2 \\
B[k]F & $\mathbf{0 . 9}$ & 0.2 & $\mathbf{0 . 8}$ & 0.4 \\
B[a]Py & $\mathbf{0 . 9}$ & 0.3 & $\mathbf{0 . 8}$ & 0.4 \\
IPy & $\mathbf{0 . 8}$ & 0.3 & $\mathbf{0 . 8}$ & 0.5 \\
DB[ah]An & $\mathbf{0 . 9}$ & 0.0 & $\mathbf{0 . 9}$ & -0.1 \\
B[ghi]Pe & $\mathbf{0 . 7}$ & 0.4 & $\mathbf{0 . 6}$ & $\mathbf{0 . 6}$ \\
\hline
\end{tabular}

Factor loadings $>0.5$ are in bold.

For TSP samples (Figure 1, Table 3), the correlation matrix [33 $\times 11]$ gave two main clusters and two significant principal components (PCs) which explain $81 \%$ of the total variance. The elements Chry and $\mathrm{B}[\mathrm{a}] \mathrm{An}$ are together in PC2 and in the same cluster. The other elements are in $\mathrm{PC} 1$ and also in the other cluster. The correlation matrix $[33 \times 11]$ gave the same cluster and PCs for $\mathrm{PM}_{10}$ samples

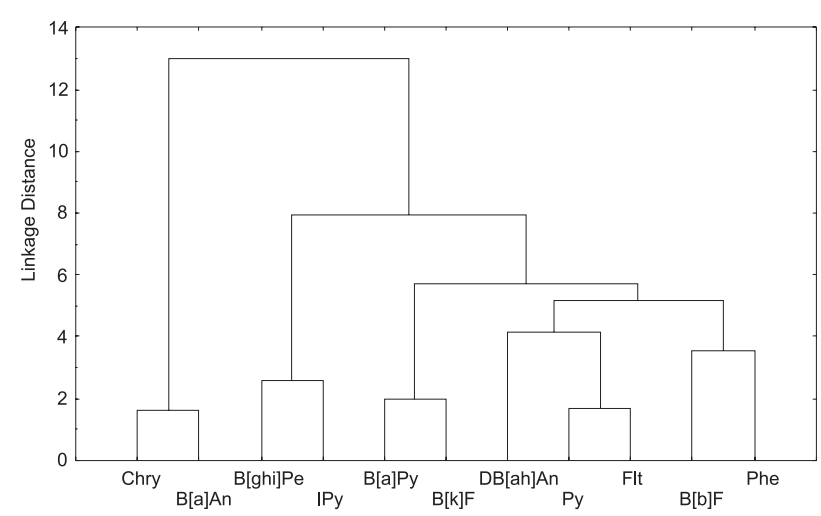

Figure 1. Dendogram of the cluster analysis of PAHs at the bus station for TSP samples. 


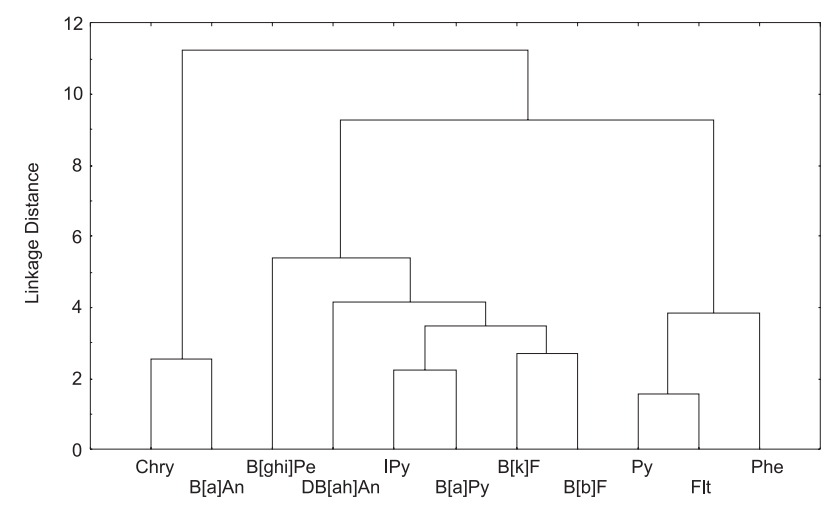

Figure 2. Dendogram of the cluster analysis of PAHs at the bus station for $\mathrm{PM}_{10}$ samples.

(Figure 2, Table 3) than for total particulate matter. The only noticeable difference is that $\mathrm{B}$ [ghi]Pe is associated both to PC1 and PC2. Also, two subgroups may be identified within the second cluster according to their liquid vapor pressures.

The Flt/Py correlation coefficient was 0.96 , in close agreement with that obtained by Pereira et al. ${ }^{38}$ It is noteworthy that these were the only compounds that gave a diagnostic ratio compatible with direct diesel emissions.

\section{Particle-associated PAHs dry deposition fluxes}

Dry atmospheric deposition fluxes $\left(\mathrm{F}_{\mathrm{d}}\right)$ were calculated by multiplying the geometric mean of each PAH concentration $\left(\mathrm{C}_{i}\right)$ in the particulate matter times the $\mathrm{PAH}$ dry settling velocity $\left(\mathrm{V}_{\mathrm{d}}\right)$ as follow:

$\mathrm{F}_{\mathrm{d}}=\mathrm{C}_{i} \times \mathrm{V}_{\mathrm{d}}$

Deposition velocity, $\mathrm{V}_{\mathrm{d},}$ may vary 1-2 orders of magnitude ${ }^{8,71-73}$ due either to particle size, climatic or physical conditions in the atmosphere Even considering those uncertainties, the particulate matter dry deposition flux calculations help to better understand PAHs removal mechanisms. Indeed, some authors, such as Vardar et al. ${ }^{71}$ and Chang et al., ${ }^{8}$ have modeled $\mathrm{V}_{\mathrm{d}}$ and they have found results comparable to those from Sheu et al. ${ }^{72}$ In this study PAH particle dry depositions were calculated using $\mathrm{V}_{\mathrm{d}}$ as stated on the latter cited study as shown in Table 4.

Dry deposition flux for the total PAHs $\left(\mathrm{F}_{\mathrm{d}}\right.$ of $\left.\Sigma \mathrm{PAH}\right)$ showed the highest value $\left(0.603 \mu \mathrm{g} \mathrm{m}^{-2}\right.$ day $\left.^{-1}\right)$ for TSP followed by $\mathrm{PM}_{10}\left(0.436 \mu \mathrm{g} \mathrm{m}^{-2} \mathrm{day}^{-1}\right)$. Individual deposition fluxes are found in Table 4. In most sites B[ghi]P was the PAH with the highest deposition flux followed by IPy.

The apparent dry deposition fluxes from Table 4 were calculated taking into account both the geometric average concentration level of an individual PAH sorbed on particulate matter and the dry deposition velocity but it should also have been taken into account PAH reactivity which can be an important parameter in interpreting the dataset. Nilsen ${ }^{74}$ has developed a reactivity scale that groups PAHs into five classes of reactivity (from Class I-the most reactive group-to Class V-the least reactive one) toward nitrating species generating then either nitro-PAHs, oxy-PAHs or quinones (these are PAH derivatives much more carcinogenic and/or mutagenic than the originating species and then of greater concern in health issues). If a PAH is more reactive than other, it is more easily modified (removed) by a photochemical reaction and it would be not found at high levels in PM and then dry or wet deposition mechanisms would not be its main atmospheric fate. On the other hand, the less reactive the PAH the more probable is to sink by either dry or wet depositions, depending on its vapor pressure and water solubility (being, therefore, probably promoted to any terrestrial and/or aquatic systems). This should be considered when analyzing some isomer pairs such as Phe and An, Flt and Py, B[b]F and B[k]F, and IPy and DB[ah]A. Flt belongs to Class V and Py is Class III then it is reasonable to accept that $\mathrm{Py}$, being more reactive than Flt, would be more readily modified to any of its possible nitro-derivatives and less Py would be available to be dry deposited..$^{75}$ The same occurs with IPy (Class V)

Table 4. Estimates of particle PAH dry deposition fluxes $\left(\mathrm{F}_{\mathrm{d}}\right)$

\begin{tabular}{lccccccccccc}
\hline Bus Station, Duque de Caxias, RJ & Phe & Flt & Py & B[a]An & Chry & B [b]F & B [k]F & B [a]Py & IPy & DB[ah]A & B [ghi]Pe \\
\hline $\begin{array}{l}\text { Dry settling velocity / }\left(\mathrm{V}_{\mathrm{d}}\right)\left(\mathrm{cm} \mathrm{s}^{-1}\right)^{*} \\
\text { TSP }\end{array}$ & 0.23 & 0.41 & 0.2 & 0.35 & 0.54 & 0.55 & 0.62 & 0.71 & 0.89 & 0.76 & 0.97 \\
Geometric mean / $\left(\mathrm{ng} \mathrm{m}^{-3}\right)$ & & & & & & & & & & \\
Dry deposition flux $\left(\mathrm{F}_{\mathrm{d}}\right) /\left(\mu \mathrm{g} \mathrm{m}^{-2}\right.$ day $\left.^{-1}\right)$ & 0.022 & 0.053 & 0.043 & 0.045 & 0.112 & 0.228 & 0.166 & 0.190 & 0.315 & 0.066 & 0.603 \\
$\mathrm{PM}_{10}$ & & & & & & & & & & \\
Geometric mean / $\left(\mathrm{ng} \mathrm{m}^{-3}\right)$ & 0.080 & 0.13 & 0.18 & 0.12 & 0.17 & 0.37 & 0.097 & 0.24 & 0.30 & 0.11 & 0.52 \\
Dry deposition flux $\left(\mathrm{F}_{\mathrm{d}}\right) /\left(\mu \mathrm{g} \mathrm{m}^{-2}\right.$ day $\left.^{-1}\right)$ & 0.016 & 0.046 & 0.031 & 0.036 & 0.079 & 0.176 & 0.052 & 0.147 & 0.231 & 0.072 & 0.436 \\
\hline
\end{tabular}

*According to Sheu et al.,$^{72} 1996$. 
and DB[ah]A (Class IV), the latter apparently possessing lower dry deposition fluxes. In the case of B $[\mathrm{b}] \mathrm{F}$ and $\mathrm{B}[\mathrm{k}]$ F pair, both belong to the same reactivity class (Class V) and their high fluxes derive from both high concentration levels and deposition velocities. Summing up, if dry deposition were the main removal mechanism for Phe, Flt, IPy, B [b]F, B [k]F and in minor extension, for DB[ah] A (and the other Class IV, Chry), those particle airborne once deposited might be resuspended by any mechanical/ physical perturbation being then able to be enriched of some PAH freshly generated (vapor-PAH converted to particle or by any physical interaction as accumulation, coagulation, etc acting in both freshly and aged particulate PAH) and be again dry deposited. This cyclic path of the PAHs could occur continuously and the particulate matter be aged in relation to some less reactive $\mathrm{PAH}$.

\section{Conclusions}

In this work the atmospheric concentrations of priority PAHs associated to TSP and $\mathrm{PM}_{10}$ samples were determined. Individual concentrations were between the detection limit (acenaphtylene, acenaphthene, anthracene and fluorene) and 2.27 and $1.74 \mathrm{ng} \mathrm{m}^{-3}$ for benzo[ghi] perylene $\left(\mathrm{B}\right.$ [ghi]P) for TSP and $\mathrm{PM}_{10}$, respectively.

$\Sigma$ PAH accounted for $0.0018 \%$ of the TSP mass and $0.0012 \%$ of the $\mathrm{PM}_{10}$ mass. The total PAH contents on the particle phase were $17.8 \mu \mathrm{g} \mathrm{g}^{-1}$ and $12.5 \mu \mathrm{g} \mathrm{g}^{-1}$ for TSP and $\mathrm{PM}_{10}$, respectively. Contributions of carcinogenic USEPA priority PAHs (B[a]An, B[b]F, B[k]F, B[a]Py, IPy and DB[ah]A) were $9.27 \mu \mathrm{g} \mathrm{g}^{-1}$ (52\% of total PAHs) and $6.73 \mu \mathrm{g} \mathrm{g}^{-1}$ (54\% of total PAHs), respectively, then, a serious health concern.

Diagnostic ratios were, in general, quite different from those determined in the exhaust of diesel vehicles suggesting an important contribution of mechanical sources and ressuspension of dust. A further study in the respirable fraction is highly desirable in order to assess the contribution of PAHs due predominantly to combustion processes.

\section{Acknowledgments}

The study was partially funded by CNPq. We would like to thank the collaboration of Marcos Menezes and Luiz Carlos de Oliveira, FIOCRUZ, for lending the high volume samplers.

\section{References}

1. Mastral, A. M.; Lopez, J. M.; Callen, M. S.; Garcia, T.; Murillo, R.; Navarro, M. V.; Sci. Total Environ. 2003, 307, 111.
2. Bodnar, E.; Hlavay, J.; Microchem. J. 2005, 79, 213.

3. Nielsen, T.; Atmos. Environ. 1996, 30, 3481.

4. Bae, S. Y.; Yi S. M.; Kim Y. P.; Atmos. Environ. 2002, 36, 5491.

5. Meudec, A.; Dussauze, J.; Deslandes, E.; Poupart, N.; Chemosphere 2006, 65, 474.

6. Vasconcellos, P. C.; Zacarias, D.; Pires, M. A. F.; Pool, C. S.; Carvalho, L. R. F.; Atmos. Environ. 2003, 37, 3009.

7. Albinet, A.; Leoz-Garziandia, E.; Budzinski, H.; Villenave, E.; J. Chromatogr., A 2006, 1121, 106.

8. Chang, K. F.; Fang, G. C.; Lu, C.; Bai, H.; Aerosol Air Qual. Res. 2003, 3, 41.

9. Chen, S. C.; Liao, C. M.; Sci. Total Environ. 2006, 366, 112.

10. Dabestani, R.; Ivanov, I. N.; Photochem. Photobiol. Sci. 1999, $70,10$.

11. Shah, S. D.; Ogunyoku, T. A.; Miller, J. W.; Cocker, D. R.; Environ. Sci. Technol. 2005, 39, 5276.

12. Manoli, E.; Kouras, A.; Samara, C.; Chemosphere 2004, 56, 867.

13. Fromme, H.; Oddoy, A.; Piloty, M.; Krause, M.; Lahrz, T.; Sci. Total Environ. 1998, 217, 165.

14. Kendall, M.; Duarte, A.; Rocha-Santos, T.; Hamilton, R.; Williams, I.; J. Environ. Monit. 2002, 4, 890.

15. Hien, T. T.; Nam, P. P.; Yasuhiro, S.; Takayuki, K.; Norimichi, T.; Hiroshi, B.; Sci. Total Environ. 2007, 382, 70.

16. Abrantes, R.; Assunção, J. V.; Pesquero, C. R.; Atmos. Environ. 2004, 38, 1631.

17. Devos, O.; Combet, E.; Tassel, P.; Paturel, L.; Polycyclic Aromat. Compd. 2006, 26, 69.

18. Durán, A.; de Lucas, A.; Carmona, M.; Ballesteros, R; Chemosphere 2001, 44, 921.

19. Yang, H. H.; Chien, S. M.; Chao, M.-R.; Lin, C. C.; J. Hazard. Mater. 2005, 125, 154.

20. Rogge, W. F.; Hildemann, L. M.; Mazurek, M. A.; Cass, G. R.; Simoneit, B. R. T.; Environ. Sci. Technol. 1993, 27, 636.

21. Marr L.C.; Kirchstter W.; Harley R. A.; Miguel A. H.; Herings S. V.; Hammonds S. K.; Environ. Sci. Technol. 1999, 33, 3091.

22. Valavanidis, A.; Fiotakis, K.; Vlahogianni, T.; Bakeas, E. B.; Triantafillaki, S.; Paraskevopoulou, V.; Dassenakis, M.; Chemosphere 2006, 65, 760.

23. Turrio-Baldassarri, L.; Battistelli, C.L.; Conti, L.; Crebelli, R.; De Berardis, B; Iamiceli, A.L.; Gambino, M.; Iannaccone, S.; Sci. Total Environ. 2006, 355, 64.

24. Turrio-Baldassarri, L.; Battistelli, C.L.; Conti, L.; Crebelli, R.; De Berardis, B; Iamiceli, A.L.; Gambino, M.; Iannaccone, S.; Sci. Total Environ. 2004, 327, 147.

25. Vasconcellos, P. C.; Zacarias, D.; Carvalho, L. R. F.; Pires, M. A. F.; Pool, C.; Atmos. Environ. 2003, 37, 3009.

26. Azevedo, D. A.; Moreira, L. S.; Siqueira, D. S.; Atmos. Environ. 1999, 33, 4987.

27. Oliveira, A. S.; Fernandes, M. B.; Moreira, J. C.; Ferreira, L. F. V.; J. Braz. Chem. Soc. 2002, 13, 245. 
28. Fernandes, M. B.; Brickus, L. S. R.; Moreira, J. C.; Cardoso, J. N.; Chemosphere 2002, 47, 417.

29. Ré-Poppi, N.; Santiago-Silva, M.; Atmos. Environ. 2005, 39 , 2839.

30. Ströher, G. L.; Ré-Poppi, N.; Raposo Jr., J. L.; Souza, J. B. G.; Microchem. J. 2007, 86, 112.

31. Pereira Netto, A. D.; Cunha, I. F.; Muniz, F. C.; Rego, E. C. P.; Bull. Environ. Contam. Toxicol. 2001, 67, 271.

32. Pereira Netto, A. D.; Muniz, F. C.; Rego, E. C. P.; Bull. Environ. Contam. Toxicol. 2002, 68, 831.

33. Pereira Netto, A. D.; Barreto, R. P.; Moreira, J. C.; Arbilla, G.; Bull. Environ. Contam. Toxicol. 2002, 69, 173.

34. Pereira Netto, A. D.; Sisinno, C. L.; Moreira, J. C.; Arbilla, G.; Dufrayer M. C., Bull. Environ. Contam. Toxicol. 2002, 68, 148.

35. Pereira Netto, A. D.; Krauss, T. M.; Cunha, I. F.; Rego, E.C.P.; Water, Air, Soil Pollut. 2006, 176, 57.

36. Lima, F. M.; MSc Dissertation, Universidade Federal Fluminense, Brazil, 2006.

37. Azevedo, D. A.; Dos Santos, C. Y. M.; Aquino Netto, F. R.; Atmos. Environ. 2002, 36, 2383.

38. Pereira, P. A. P.; de Andrade, J. B.; Miguel, A. H.; J. Environ. Monit. 2002, 4, 558.

39. Miguel, A. H.; Pereira, P. A. P.; Aerosol Sci. Technol. 1989, 10, 292.

40. Martinis, B.; Okamoto, R. A. B.; Kado, N. Y.; Gundel, L.; Carvalho, L. R. F.; Atmos. Environ. 2002, 36, 307.

41. Santos, C. Y. M.; Azevedo, D. A.; Aquino Neto, F. R.; Atmos. Environ. 2002, 36, 3009.

42. Quiterio, S. L.; Arbilla, G.; Bauerfeldt, G. F.; Moreira, J. C.; Water, Air, Soil Pollut. 2007, 179, 79.

43. Miguel, A. H.; de Andrade, J. B.; Hering, S. V.; Int. J. Environ. Anal. Chem. 1986, 26, 265.

44. Bourotte, C.; Forti, M. C.; Taniguchi, S.; Bícego, C.; Lotufo, P. A.; Atmos. Environ. 2005, 39, 3799.

45. Dallarosa, J. B.; Mônego, J. G.; Teixeira, E. C.; Stefens, J. L.; Wiegand, F.; Atmos. Environ. 2005, 39, 1609.

46. Dallarosa, J. B.; Teixeira, E. C.; Meira L.; Wiegand, F.; Atmos. Environ. 2008, 89, 76.

47. Dallarosa, J. B.; Teixeira, E. C.; Pires, M.; Fachel, J.; Atmos. Environ. 2005, 39, 6587.

48. Tavares Jr, T.; Pinto, J. P.; Souza, A. L.; Scarmínio, I. S.; Solci, M. C.; Atmos. Environ. 2004, 38, 5039.

49. Corrêa, S. M.; Arbilla, G.; Atmos. Environ. 2006, 40, 6821.

50. Wingfors, H.; Sjodin, A.; Haglund, P.; Brorstrom-Lundén, E.; Atmos. Environ. 2001, 35, 6361.

51. http://www.duquedecaxias.rj.gov.br/web/cgi/cgilua.exe/sys/ start.htm, accessed in April 2007.
52. http://www.detran.rj.gov.br, accessed in July 2007.

53. http://www.epa.gov/ttnamti1/files/ambient/inorganic/mthd-3-1. pdf, accessed in July 2006

54. http://www.epa.gov/Region9/qa/pdfs/40cfr136_03.pdf, accessed in July 2006

55. http://www.epa.gov/epaoswer/hazwaste/test/pdfs/3550c.pdf, accessed in July 2006

56. http://www.epa.gov/epaoswer/hazwaste/test/pdfs/8270c.pdf , accessed in July 2006

57. Ciganek, M.; Neca, J.; Adamec, V.; Janosek, J.; Machala, M.; Sci. Total Environ. 2004, 334-335, 141.

58. Guo, H.; Lee, S. C.; Ho, K. F.; Wang, X. M.; Zou, S. C.; Atmos. Environ. 2003, 37, 5307.

59. Venkataraman, C.; Lyons, J. M.; Friedlander, S. K.; Environ. Sci. Technol. 1994, 28, 555.

60. Cotham, W. E.; Bidleman, T. F.; Environ. Sci. Technol. 1995, 29, 2782.

61. Harrison, R. M.; Smith, D. J. T.; Luhana, L.; Environ. Sci. Technol. 1996, 30, 825.

62. Alves, C.; Pio, C.; Duarte, A.; Atmos. Environ. 2001, 35, 5485.

63. Mantis, J.; Chaloulakou, A.; Samara, C.; Chemosphere 2005, 59, 593.

64. Rogge, W. F.; Hildemann, L. M.; Mazurek, M. A.; Cass, G. R.; Simoneit, B. R. T.; Environ. Sci. Technol. 1993, 27, 1892.

65. Kavouras, I. G.; Lawrence, J.; Koutrakis, P.; Stephanou, E. G.; Oyola, P.; Atmos. Environ. 1999, 33, 4977.

66. Kavouras, I. G.; Koutrakis, P.; Tsapakis, M.; Lagoudaki, E.; Stephanou, E. G.; Von Baer, D.; Oyola, P.; Environ. Sci. Technol. 2001, 35, 2288.

67. Sienra, M. R.; Rosazza, N. G.; Préndez, M.; Atmos. Res. 2005 , $75,267$.

68. Oda, J.; Nomura, S.; Yasuhara, A.; Shibamoto, T.; Atmos. Environ. 2001, 35, 4819.

69. Alves, C.; An. Acad. Bras. Ciênc. 2008, 80, 21.

70. Marino, F; Cecinato, A; Siskos, P.A.; Chemosphere 2000, 40, 533.

71. Vardar, N.; Odabasi, M.; Holsen, T. M.; J. Environ. Eng. 2002, 128, 269.

72. Sheu, H.-L.; Lee, W. J.; Su, C. C.; Chao, H. R.; Fan, Y. C.; J. Environ. Eng. 1996, 122, 1101.

73. Fang, G. C.; Chang, K. F.; Lu, C.; Bai, H.; Chemosphere 2004, 55,787 .

74. Nielsen, T.; Environ. Sci. Technol. 1984, 18, 157.

75. Tasdemir, Y.; Esen, F.; Atmos. Environ. 2007, 41, 1288.

Received: November 4, 2008 Web Release Date: August 31, 2009 